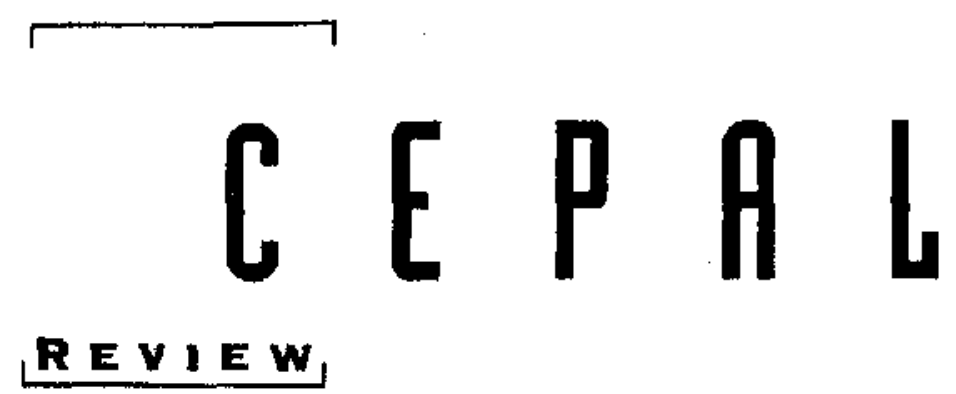

\author{
NUMEEF 65 \\ AUQUST 1998 \\ SANTIAGO, CHILE \\ O S CA ALTIMIA \\ Director of the Review \\ EUGENIO LAHEAA \\ Technical Secretary
}

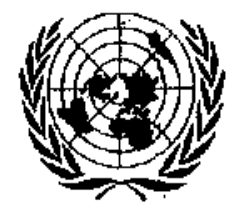


Income distribution, poverty and social expenditure In Latin Amerlca

José Antonio Ocampo

Military expenditure and development in Latin America

Eugenio Lahera and Marcelo Ortuzar

Growth, dlstrlbutive justice and social policy

Andrés Solimano

Equity, forelgn investment and International competitiveness

Adolfo Figueroo

Tensions in Latin American structural adjustment:

allocatlon versus distribution

Daniel M. Schydlowsky

Compethliveness and labour regulations

Luis Beccaria and Pedro Galín

Latin American femilles: convergences and divergences in models and pollcles

Irma Arriagada

Free trade agreements and female labour: the Chilean sltuation

Alicia Frohmann and Pilar Romaguera

Macroeconomic trends in Paraguay from 1989 to 1997:

consumptlon bubble and financial crisis

Stephane Straub

The strategies pursued by Mexican firms in their efforts

to become global players

Alejandra Salas-Porras

Pegulating the private provision of drinking water and sanitation services

Terence R. Lee and Andrei S. Jouraviev

Quallty management promotion to Improve competitiveness

Hessel Schuurman

Recent ECLAC publlcations 


\section{Competitiveness and labour regulations}

\section{Luis Beccaria \\ Pedro Galín}

This article analyses the relations between the competitiveness of an economy and the labour regulations in force in it. It is argued that economic theory is not conclusive regarding the impact of labour regulations on competitiveness, since different schools of thought maintain opposing positions in many respects. Moreover, empirical research has shown that the information provided with respect to these assumed linkages is not very relevant. Various policy consequences follow from this: coumtries have a variety of strategies at their disposal and greater leeway that is usually suggested, since many policies aimed at improving equity do not necessarily involve any restrictions on competitiveness. A country can therefore choose the desired level of social protection. The improvement of competitiveness becomes, at least partly, a matter of income distribution. The most conventional formula proposes the reduction of workers' quality of life for a period whose duration is difficult to forecast, with the aim of providing enterprises with certain initial conditions which will allow them to make up for differences in productivity. This is not the only formula, however, nor is it the mast equitable or effective. In order to generate those same conditions, income redistribution schemes can be designed which make investment for international competitiveness attractive, without resorting to further erosion of the wages of those who were most seriously affected during the last years of application of the import substitution models. The analysis made suggests that there is ample leeway for choosing between vartous combinations of equity and efficiency, and their selection depends on the power relations of the various social actors and the structure of the Stale. 


\section{I}

\section{Introduction}

Competitiveness and labour regulations, which are the main subjects of this article, relate to issues of great scope and enormous repercussions which go back a long way in history.

It is not a question of the relations between two different sciences (such as economics and labour law), ${ }^{1}$ or between two facts, but between an economic phenomenon -competitiveness- and labour law, understood here as positive law of broad scope (including social security). Labour regulations do not of course only involve costs: their main functions include the protection of both workers and production, since they organize the latter and establish "industrial legality". Although this issue is dealt with here from an interdisciplinary standpoint, it should be noted that whereas there are an enormous number of studies on this matter in the economic literature, there are only a few quite isolated contributions dealing with labour law.

With regard to the antiquity of this matter, it may be recalled that in the debate over laws to limit the working day it was frequently argued that these would ruin the industries of any country which adopted them, because of international competition from those which did not apply such rules. The preamble to the Constitution of the International Labour Organisation declares that "Whereas also the failure of any nation to adopt humane conditions of labour is an obstacle in the way of other nations which desire to improve the conditions in their own countries", and the original British proposal for the formation of the no stated that one of the main objectives of the new organization was to do away with competition based on sub-human working conditions. ${ }^{2}$ The current debates and arguments also contain reminders of some quite far-off controversies: a recent publication reproduced an article originally published in 1927.

$\square$ A preliminary version of this paper was presented at the IX Jornadas Rioplatenses de Derecho de Trabajo y de la Seguridad Social (Punta del Este, 11-12 May 1996).

${ }^{1}$ It would appear that labour law has not escaped an onslaught "such as has not been seen since the $1890 \mathrm{~s}$ : a deliberate tendency to impose the monopoly of economic method on all studies of society", as Adam Przeworsky noted a decade ago (Przeworky, 1987, p. 97). which it included in order to show that the present economic problems are not totally different from those which existed then. ${ }^{3}$

The repercussions of this matter are not exclusively academic. On the contrary, it involves the interests and positions of various social and political forces and States, with differing interpretations of the values of social justice, protectionism, international competition and even the preservation of civilization. The most heated international debates are currently about the "social clauses" or the so-called social dimensions of the liberalization of international trade: a matter which warrants a specific study on it and will therefore not be dealt with here.

These three features: the broad scope, antiquity and importance of the issue, make it necessary to limit the objectives of this study: we will set forth here what is currently known about the matter without pretending to make original contributions or substantive empirical additions to the existing body of knowledge.

The layout of the article will be as follows: section II will set forth the main approaches of economic theory, often stylized both in order to save space and for institutional reasons: there will be no econometric expositions, which would be long and tedious for the present context. Section III sets forth the most recent arguments put forward in the specific debate on labour regulations. The effects of such regulations, as indicated by empirical studies, are dealt with in section IV, which also includes the most salient aspects of the way in which this matter is being dealt with in Argentina, Finally, section V sets out some final reflections.

With regard to the sources, most of the contributions come from the economic literature, since there are few legal studies on this matter.

\footnotetext{
${ }^{2}$ Cited by Caire, 1994.

3 The 1927 article was by Herbert Feis, reproduced in Sengerberger and Campbell, eds., 1994, pp. 29-55.

${ }^{4}$ In the Argentine legal literature we only found two articles: those by Armando Caro Figueroa, 1992, p. 383 et seq, and Geraldo von Potobsky, 1995.
} 


\section{II}

\section{Economic theory and State intervention}

This section briefly sets forth the basic economic arguments on State intervention, in onder to provide a frame of reference for mone specific consideration of the impact of labour regulations on competitiveness.

With regard to State intervention, conventional neoclassical thinking asserts that the market -if allowed to operate without interference- ensures achievement of the greatest possible well-being of the population. It does, however, offer two justifications for State intervention: on the one hand, the presence of market flaws such as the existence of monopolies, oligopolies, monopsonies or oligopsonies, externalities, lack of information, or the fact that public or free goods are involved, and on the other hand, the need to change income distribution when the result of the free play of the markets is considered to be unsuitable. In reality, it concerns interventions seeking to move the economy from one optimal state (optimal from the point of view of efficiency) to inother.

Neoclassical economists point out, however, that State action does not always improve aggregate wellbeing even when there are market flaws or distribution is manifestly inequitable. Thus, for example, it is usually argued that many interventions based on the objective of redistribution do not keep the system on the leading edge of its potential but bring it to points which are below that level, thus causing a reduction in global efficiency. Actions based on the existence of market flaws are also open to question because there may be "government flaws", especially as public interventions are designed mainly in the light of the objectives of politicians or bureaucrats, thus leading to losses of efficiency greater than those deriving from the presence of externalities, public goods or monopolies.s

Neoclassical authors assert that in a dynamic context State interference leads to unsuitable resource allocation which affects the growth capacity of the economy by reducing the profitability of investments, discouraging saving or giving signals which lead to a reduction of investment in the activi-

\footnotetext{
5 Accorting to Self (1993), neoclassical authors lay frequent stress on the many opportunities that bureaucrats have to distort policy objectives for their own benefit.
}

ties with the greatest growth potential. Furthermore, in an open economy State intervention is also alleged to alter the structure of incentives, thus diverting many investments towards branches which have fewer advantages and thereby causing inefficient resource use, lowering the global competitiveness of the economy and reducing its growth capacity.

The criticisms of these basic postulates of neoclassical thinking made by heterodox neoclassical authors or those who do not support this school of thought are located on two levels of analysis. On the one hand, there are conceptual differences regarding the impact of regulations and institutions on economic efficiency, and on the other hand there are controversies about empirical questions regarding the very existence of certain market flaws or the quantitative impact that various kinds of intervention can have on efficiency.

With regard to the conceptual discussion, it is stressed that certain institutions have a positive impact on efficiency, and it has also been asserted that prices do not only constitute a signal for the allocation of resources but also influence the quality of the product. In these circumstances, the free play of the market does not always automatically achieve optimal results (Stiglitz, 1987). There may also be possible conflicts between the short term (inefficient resource allocation) and the long term (increased productivity). Protectionist trade policies were justified precisely on the basis of the infant industry argument or, in more general terms, the need to "create" competitive advantages.

Another idea which is in opposition to the orthodox view is that the economic determining factors leave a more or less broad margin for the actors involved -buyers or sellers, workers and entrepreneursto negotiate levels of prices and quantities without this adversely affecting efficiency. This means that in all cases buyers and sellers have some bargaining power, thus making necessary various institutions to regulate exchanges and balance the natural differences in the competitiveness of the actors.

With regard to the discussion about the very existence of market flaws, neo-Keynesian thinking 
holds that many of them -such as the capacity to exercise some degree of control over the market- are very important and prevent adjustment to optimal levels. With regard to the appraisal of the distortions that regulation might cause, a number of studies have shown that some of its costs in terms of inefficiency are not significant compared with its clear positive impact on income distribution.

\section{III}

\section{Labour regulations}

In the preceding section we briefly reviewed the positions of neoclassical economists -and also of some schools of thought which are critical of this orthodox view- on State intervention in general. In this section we will concentrate specifically on the development of the different analytical approaches regarding labour regulations.

The archetypal expressions of the orthodox view in this respect are, with regard to supply, that any programme which protects the population from the consequences of unemployment gives an incentive not to work at all and is a hindrance for the economy, and with regard to demand, that social assistance changes employment decisions in a socially inefficient manner (Blank and Freeman, 1994).

From the orthodox perspective, unemployment benefit programmes or social security benefits can lead workers to prefer idleness to work until such benefits run out; this increases the well-being of the beneficiaries, but reduces the global social product and prolongs unemployment. Programmes which establish compulsory social benefits may constrain workers' choices, leading to suboptimal and inefficient results and higher labour costs. Generous sickness benefits can lead to an epidemic of headaches, backaches and similar ills until the coverage of sick leave is completely used up.

In terms of the demand for labour, it is considered that regulations limiting the hiring or firing of workers, for example, can distort the labour market signals and reduce profitability because of over-manning or else cause employers to take on fewer workers in expectation of higher future costs. Laws which impose taxes on employers to finance retirement pensions of unemployment benefits may cause firms to under-declare the wages actually paid or may make it uneconomic to hire low-income workers, depending on the rate of such taxes. Legally fixed minimum wages may reduce employment in low-wage activities or occupations.
This approach emphasizes the distorting effects exerted on saving and investment by the taxes needed to finance such programmes. These programmes, it is claimed, divert capital away from more fruitful investment options and hence, if the latter options had greater potential for job creation, the money spent on sustaining low-income families could lead to a permanent reduction in job opportunities, leaving those families, like the rest of society, in worse conditions in the long run. Many such programmes expand public sector employment, thus further strengthening labour market rigidities.

Finally, the orthodox approach claims that in an open economy there is a further adverse impact if social protection programmes have any of the negative effects mentioned above, because by increasing labour costs, protective legislation may reduce international competitiveness. We shall return to this point later.

The opponents of the orthodox neoclassical school, who base their views, as we already noted, on various different theories, formulate a number of reservations regarding approaches like those reviewed above.

Firstly, they highlight the role of social protection programmes in increasing human capital and productivity in the labour market. According to this viewpoint, labour regulations can create long-term incentives for investment in training (Blank and Freeman, 1994; Standing, 1992; Boyer, 1994). If there are restrictions on the dismissal of workers, there is an inducement for employers to invest more in training the labour force, since these laws give rise to long-term relationships which make investment in specific training a profitable proposition.

In other respects, long-term links may give rise to higher productivity of workers through, for example, their identification with the aims of the enterprise and their loyalty to it. 
The theory of "efficiency wages" also provides various arguments in favour of the beneficial effects of equitable treatment of workers. According to this approach, wages are not just an allocation mechanism but also a means for promoting the efficiency of the labour force. Consequently, preventing wage rates from going down too much would have a positive effect on productivity. Some versions of this approach, in particular, see wage-earners' attitudes in a different light from the neoclassical approach: workers do not try to reduce the effort needed to carry out their tasks - a view which is implicit in the idea that this effort reduces the individual's own gain- but always make a given effort, which can be influenced by the remuneration they receive: workers who consider themselves to be fairly treated will assuredly work harder (Akerlof and Yellen, 1988, p. 45).

Minimum wages, which have been criticized, as already noted, on the grounds that they reduce the demand for less skilled workers, are considered to have a possibly beneficial effect on efficiency by increasing the supply of such groups.

Furthermore, orthodox arguments about the distorting effects of regulations usually take as their frame of reference a situation of perfect competition, without analysing the global economic context, in which there are market flaws and other regulations. An example of this is the British legislation on equal pay adopted in the early 1970s: in contradiction of neoclassical theories, there is no proof that the relative increase in women's wages brought about by this law has been reflected in any reduction in female employment, which may be due to the fact that the paradigm of perfect competition did not fully apply and employers exerted some degree of control over the market. In this context, the law made it possible to increase overall efficiency (Gregg, Machin and Manning, 1994, p. 109).

From a more empirical standpoint, some heterodox authors note that although protective regulations do have distorting effects on labour markets, no measurement is made of the benefits that they bring. which are in any case difficult to quantify (Blank and Freeman, 1994, pp. 31 and 32; Sengerberger and Campbell (eds.), 1994, pp. 13-14; Standing, 1992). The economic benefits of labour regulations -some of which were already mentioned earlier- are indirect, hidden, intangible, spread over time and not localized (Boyer, 1994, p. 26). Mention has been made in this respect of the example of the costs imposed by regulations on bealth and safety, which are generally easy to estimate, as are some of the benefits they generate (saving of outlays on the treatment and replacement of workers injured in accidents, for example), which may exceed such costs. It is more difficult to estimate the loss of productivity and purchasing power and the total amounts lost in some recent very costly industrial accidents (Sengerberger and Campbell (eds.), 1994), not to mention human values which cannot be measured in economic terms, such as life and health. Many of these phenomena also generate negative externalities which are generally hard to calculate. In order to make a full costbenefit analysis of each social programme, it is necessary to compare the increase in the economic well-being of citizens with the direct and indirect costs involved. A mere demonstration of the distorting effects or the costs in terms of inefficiency is not enough (Blank and Freeman, 1994, p. 32).

This latter observation also points up the fact that orthodox arguments generally fail to take into account the effect of protective rules and institutions on income distribution. Institutions like trade unions not only play an important role from the point of view of efficiency, by reducing transaction costs, but also tend to offset the natural difference in bargaining capacity between workers and employers. Indeed, insofar as employers recognize a certain amount of power of the market, as noted in a previous paragraph, trade unions increase rather than reduce efficiency.

Heterodox thinkers maintain that the assertion that labour regulations or social programmes reduce economic growth is weak even in terms of orthodox economic theory. The analyses indicate a loss of efficiency in static terms, but not a reduction in growth rates. Growth theory does not provide any clear predictions on how static distortions alter the rate of economic development. Indeed, in line with various arguments mentioned above, short-term inefficiencies can be offset by dynamic efficiency.

Some specific comments on the subject of competitiveness are called for in concluding this section. Competitiveness does not depend only on efficiency or relative productivity. A country can flood another nation with goods that it produces less efficiently if the difference in the prices of the inputs and factors that enter into their production is greater than the difference in the efficiency with which those inputs 
or factors are used. ${ }^{6}$ From an aggnegate standpoint, this means that a country can be "competitive" on the basis of low wages. Consequently, lower competitiveness does not always mean less chance of competing, but a lower standard of living.

The orthodox approach holds that the relative decline in productivity may only give rise to a temporary reduction in competitiveness, because the market mechanisms cause a drop in wages and/or other factor prices (exports go down and/or imports go up, thus leading to a drop in production and employment) which tends to restore competitiveness. As this self-regulating mechanism is felt to be partially impeded by the existence of labour regulations, it is proposed that these should be reduced: this would reduce wage costs, thereby improving competitive-

\section{IV}

\section{Empirical data}

Now that we have briefly set forth the theoretical arguments regarding the incidence of labour regulations on competitiveness, it is worth looking at the empirical data adduced in support of the respective positions. Generally speaking, the data have been prepared in the light of the differences between the behaviour of the developed countries, particularly those of the Organization for Economic Cooperation and Development (OECD), on the one hand, and the countries of the South, on the other.

A general assertion may be made at this point which serves to sum up the conclusions of this section: when we analyse the arguments on the relations between social protection programmes, labour market flexibility and aggregate economic well-being, we see that very little information is available on numerous questions (Blank and Freeman, 1994, p. 36).

\section{The induatrialized countries}

With regard to the developed world, comparisons have been made between, on the one hand, the Euro-

6 The greater competitiveness displayed by a given activity is not due solely to its greater efficiency and/or the lower prices prevailing in it. It may also be due to the lower prices paid for inputs (whose production may be very efficient and/or involves the payment of low factor prices) or for consumer goods (which means that wages can be lower). ness and making the activities in question more attractive to investments, and this would lead in time to a rise in productivity and -in a context of growing employment- in wages too.

The heterodox criticisms of this approach point out, firstly, that the improvement in competitiveness based on lower wages: i) leads to the abandonment of the quest for increased efficiency; ii) encourages specialization in relatively simple goods which require relatively unskilled labour and usually have little future; and iii) does not really constitute a strategy, since it cannot be repeated and its effects are overtaken by the increases in productivity in other countries. Secondly, they question, on the grounds already mentioned earlier, the orthodox idea that denegulation and lower wages favour increased productivity.

pean economies -especially those of the European Union- which have extensive regulations and social protection machinery, and on the other the United States, where social security benefits and labour regulations are notably looser. The analysis has often also been extended to Japan, which has stricter labour regulations and social protection systems than the United States, although the level of collective bargaining is decentralized.

In principle, the orthodox school considers the United States as a model country in terms of competitiveness because of its limited regulations, whereas the European Community is seen as representing the opposite.

The most systematic study made by the orthodox school is probably that which analyses the behaviour of the OECD countries which bave signed regional trade agreements: i.e., the European Economic Community (EEC), the European Free Trade Association (BFTA), made up of the Scandinavian countries, Switzerland and Austria, and the North American Free Trade Agreement (NAFTA). ${ }^{7}$ This study analyses the regulations and provisions regarding working hours, contracts, minimum wages and rights of representation of workers and concludes

\footnotetext{
${ }^{3}$ In reality, Mexico is not analysed for lack of information.
} 
that there is no single direct relation between labour regulations and trade results, but that it is too soon to draw a final conclusion in this respect and that more empirical research is needed (OECD, 1995). A more recent study by the same organization (OECD, 1996) mentions the difficulties encountered in trying to make an empirical analysis of the links between basic labour standards and trade flows, the main limitation being the fact that the available information on basic standands is limited and incomplete, except with regard to freedom of association and collective bargaining. The conclusions of the study therefore refer mainly to the latter two basic standands. The empirical data confirm the analytical results whereby basic labour standards have hardly any influence on trade performance. The idea of sinking to a lowest common denominator in the sense that countries with mediocre standands win portions of the export market at the expense of those with good standards is not confirmed by empirical observation. According to the conclusions of this study, the developing countries have no empirical justification for believing that an improvement in basic labour standards would adversely affect their economic performance or competitiveness in world markets.

This skepticism about correlations between protective regulations and productivity is shared by other international organizations. Thus, an official ILO document asserts that the theoretical advantages of open, decentralized competition in the labour markets must be contrasted with the fact that three of the world's most successful economies- the United States, Japan and Germany- have vastly different systems of wage fixing, union density, levels of negotiation and forms of coordination of the whole economy. The most elementary conclusion is that such disparities do not count as far as global employment and other macroeconomic variables are concerned (ILO, 1995). Several documents of different tones have been prepared in the European Commission. One of them states that there is general agreement that the labour markets do not work well and that the origin of the rigidities observed is the lack of flexibility of the labour market, especially from the point of view of the organization of working time, wages and mobility (European Commission, 1994a). In another official document, however, the "general agreement" on this matter is questioned and it is noted that there are those who argue that excessively restrictive labour regulations entail costs that reduce the competitiveness of firms in on country or region companed with others. On the other hand, many experts believe that productivity and high labour standards have always been an integral part of the competitive formula. The tension between these two points of view has been very evident and it must be admitted that there is no clear agreement on this point (European Commission, 1994b). A study published by the United Nations.Conference on Trade and Development (UNCTAD) states that there is no empirical information to support or deny the claim that loose labour rights give a competitive advantage in trade, so that studies in greater depth need to be carried out on each of the labour standards in question (De Castro, 1995, pp. 9 and 10).

Nor are there any studies which provide conclusive data in this respect in the academic field. At the Fourth European Regional Congress of the International Industrial Relations Association the main topic was the competitive advantages of European, United States and Japanese industrial relations, and the official report noted that the documents prepared were marked by cautious attitudes and reserved judgments with regard to the advantages and potential development of the European, Japanese and United States blocs. According to those documents, none of the properties behind those three great world blocs was generally superior to its competitors, since each of them had its relative merits and disadvantages (Jacobi, 1994, p. 18). Another study highlights the complexity of the subject and the "over-simplification" displayed by the various interpretations, although in some cases certain labour regulations, such as the extremely rigid Italian regulations on hiring or the lack of regulations to protect job security in the United States, may be associated with a loss of global economic efficiency (Buechtemann, 1993, p. 62). Other studies note that although the United States the industrialized country with the most flexible labour regulations and the lowest degree of social protection-has had the highest productivity in the world for a number of decades, it will lose that leading position towands the year 2000 and be overtaken by France and Belgium, since its productivity growth rate is below that of the OECD countries, except for Australia and the Netherlands (Freeman, 1994, p. 9). Nor are categorical conclusions reached in a comparative study of five industrialized countries the United States, France, Great Britain, Germany and Sweden) on competitiveness and the Welfare State, 
since it is noted that while lack of economic discipline can cause the Welfare State to be at odds with competitiveness in terms of prices, productivity and quality are nevertheless benefited by it (Pfaller, Gough and Therborn (eds.), 1993, p. 368 et seq.). In another more recent study it is asserted that both the theory and the empirical data give few reasons for believing that differences in labour regulations make a significant contribution to differences in production costs and, hence, to investment and trade pattems. ${ }^{8}$

In the light of the wide range of studies examined, it may be suggested that there is no empirical information which backs up the existence of linkages between labour standards and competitiveness, even with regand to the general direction in which those linkages operate.

\section{The developing countries}

It has been hotly argued that liberalization of the labour market is an essential feature in the structural adjustment programmes that the developing countries need to apply in order to stimnlate the economy and successfully integrate it into the world market by improving its competitiveness. This orthodox approach maintains that over-regulation of the labour market in Latin America has both entrenched labour market dualism between a highly protected urban formal sector and a largely unprotected informal sector and has impeded labour market adjustment to changing market forces. In contrast, it is argued that labour markets are only sparsely regulated in the recently industrialized Asian countries and that this has been an essential factor behind the successful implementation of export-led development strategies. It is also claimed that the repression of trade unions especially in their wage-setting role- has contributed to this (IIO, 1995, p. 93).

Followers of the heterodox school of thought, however, have claimed that in the light of these repressive interventions it is rather ingenuous to expect that price distortions can be avoided in successful cases of industrial growth (Standing, 1992, p. 26). It has also been said that the repression of trade unions was not completely generalized (Hong Kong re-

${ }^{8} \mathrm{~K}$. Anderson, The entwining of trade policy with environmental and labour standards, paper presented at the World Bank conference on the Uruguay Round and the developing economies (26-27 January 1995), quoted by De Castro, 1995, p. 10. spected British liberal traditions, yet its economic performance was as successful as that of the other "tigers"). In Singapore and Taiwan, a different manner of intervention in the trade unions was used: they were kept under control through a single party. Thanks to its participation in the National Wages Council, the trade union movement in Singapore has been able to exert some influence on economic and social policies, within admittedly narrow limits. At all events, along with the intervention in the $1970 \mathrm{~s}$ which was aimed at restricting wage rises to keep them below ODP growth, wage correction policies were adopted to tackle the shortage of labour and encourage firms to enter into more technologically complex activities.

The question has been raised of whether these labour market control systems in Southeast Asia were really necessary for those countries' competitive success. As the World Bank itself notes, generally speaking workers are more willing to accept wage flexibility when there is a rapid upwand trend, because a downward adjustment only means a slower rate of increase rather than an absolute reduction in real labour income." In other words, the constant rise in real wages observed in the "Asian Tigers" would appear to have facilitated the generalized acceptance of flexible wages even though their rate of increase has been lower than that of productivity. At the same time, the degree of State intervention in the economy was very intense, with very active industrial policies of a coercive nature which may have had a much more decisive influence on the economic success than deregulation of the labour market or, more exactly, its repressive or paternalist regulation, as noted by Standing $(1992$, p. 38). It has been asserted that one of the most important features of South Korea's economic development is probably the strong role of the State, especially in its capacity to influence and discipline the great companies which dominate the Korean economy (Park, 1994a, p. 209). It has also been asserted that what enabled the East Asian countries to discipline their companies was the relative weakness of both the industrial and the agricultural groups at the beginning of the post-war industrial development process. ${ }^{10}$

9. Fields, "Changing labor market conditions and economic development in Hong Kong, the Republic of Korea, Singapore and Taiwan", in World Bank Economic Review, vol. 8, No. 3, quoted in 110,1995, p. 95.

10 A. Amsden, "A theory of government intervention in late industrialization", cited by Hikino and Amsden, 1995, p. 6. 
Finally, the growing incorporation of protective institutions -the minimum wage in South Korea and Taiwan, and unemployment insurance in South Korea- and the growing independence of the trade union movement do not seem to have altered the growth rates of these countries. "These policy developments in Asia thus highlight the fact that neither a totally deregulated labour market nor labour repression is indispensable for success in export markets" (ILO, 1995).

Other views even question whether State intervention in South Korea has been exclusively repressive and consider that it is necessary to take into account the important patemalist elements in labour policies over the last 30 years. In order to gain competitiveness in international markets, labour was extensively regulated by the government. This did not necessarily mean, however, that the intervention in the labour market was aimed exclusively at benefitting employers. In order to prevent exploitation of workers in view of the absence of (collective) labour rights, the government took a number of protective measures and even encouraged employers to improve working conditions as far as was compatible with the degree of economic development (Park, 1994b). A World Bank study has noted that the South Korean government intervened to ensure that wages did not increase faster than productivity, but that, at the same time, workers shared in the fruits of growth (Mazumdar, 1994). Although trade union autonomy was restricted, the revisions of labour legislation in the early 1960 s strengthened individual protection. In spite of the severe repression of collective rights, the revisions of the labour legislation in 1970 included some measures to increase workers' well-being, and in 1981 a number of measures were taken to improve health and safety regulations. An analysis of the history of labour legislation shows that the State continued to increase protection of individual labour relations, while at the same time reducing the legal provisions protecting collective relations. Since 1965 , real wages have grown at a cumulative annual rate of $7.5 \%$, which surpassed the performance of all the industrialized countries, including Japan, in periods of rapid growth. Income distribution also improved substantially, becoming more equal, and the share of wage eamers' income in total national income rose from $31.8 \%$ in 1965 to $59.7 \%$ in 1990 . Although the South Korean working day is the longest and the incidence of accidents is the highest among all the countries supplying data to the ILO's Labour Statistics Yearbook, the length of the working day has gone down significantly since 1980 , and with regard to accidents, these are said to be recorded more fully than in other countries (Park, 1994b).

In more general terms, a strong correlation has been found, in a sub-sample of recently industrialized countries, between equality of income distribution and productivity growth (Hikino and Amsden, 1995, p. 17).

The orthodox argument is well known in Latin America: by altering the relative retums of the various sectors, tariff barriers and the high degree of State involvement are supposed to have given rise to economies with little growth capacity and/or serious macroeconomic instability. Labour legislation, in particular, is supposed to have deprived the labour market of flexibility, increased non-wage costs and, in some cases, excessively increased the capacity of the unions to exert pressures. This, it is alleged, explains a level of wage costs which is not in keeping with the productivity achieved, thus adversely affecting the competitiveness of those economies and their capacity to generate productive employment. This is reflected, it is claimed, in a high degree of underutilization of labour which is manifested in the high proportion of informal workers; the resulting segmentation is said to largely explain the unequal personal income distribution, and the low rates of growth of production and generation of employment have meant that in the long term the share of wages in national income was not able to increase.

Comparative studies made in the Latin American context, however, share the general skepticism about the conclusiveness of the available information. Thus, it has been asserted in a World Bank study that if, for example, the relatively successful adjustment of Costa Rica is contrasted with the problems en countered by Bolivia, it is clear that the dismantling of labour institutions is neither necessary (Costa Rica) nor sufficient (Bolivia) to ensure that an adjustment has satisfactory results. It is added that in future studies it would be useful to analyse the role of labour institutions, trade unions and economic policy before embarking on a global defence of the dismantling of such institutions (Horton, Kanbur and Mazumdar, 1994, pp. 45 and 57).

From a different standpoint, it has been asserted, on the basis of an analysis of the labour protection systems of Mexico, Colombia, Peru, Argentina, Chile, Brazil and Uruguay, that it is by no means 
clear that labour legislation has any clear effects on overall industrial productivity and that the principle underlying the present policy proposals of a number of Latin American countries -namely, that it is sufficient to make the regulations on dismissal and labour contracts more flexible in order to improve the economic results- is based on a serious misconception (Marshall, 1994, pp. 76-77).

An even more recent study seeks to establish whether reduction of labour costs is necessary in order to improve competitiveness. The analysis concentrates on the evolution of the manufacturing sector over the period 1990-1995 in Argentina, Brazil, Chile, Mexico and Peru. It is concluded that although labour costs rose in four of the five countries studied, productivity rose even more. This shows that labour costs are not an impediment to higher competitiveness, since the evolution of the latter is determined more by labour productivity than by labour costs. The study concludes that the increase in labour costs measured at international prices -which could have affected competitiveness-- was due mainly to macroeconomic policies which have established overvalued exchange rates with respect to the dollar and hence alterations in relative prices to the detriment of prinary and industrial goods. This has meant that the increase in such labour costs for emrployers in the tradeable goods sector has not necessarily been reflected in proportional improvements in the real wages of workers. Industrial wages grew over the period in question, but at the end of it they were lower than in 1980 in Argentina (-21\%), Mexico $(-38 \%)$ and Peru $(-57 \%)$, while they were $10 \%$ higher in Brazil and $29 \%$ higher in Chile (Tokman and Martínez, 1995). In other words, there is no conclusive evidence of an association between labour legislation (expressed as total labour costs) and competitiveness, since the decisive variables are of a different nature.

In short, the information available from the studies on Southern countries is not conclusive with regard to a possible relation between labour institutions and competitiveness: both World Bank studies and those of the ILO question the simplistic approaches which directly associate deregulation or absence of rules with competitive advantages. At all events, more research is needed to clarify the complex interrelations among the host of variables which determine competitiveness, not only in the short term but even more so in the long term, as the studies on South Korea suggest.

\section{Argentina}

The proposal to abandon the accumulation model based on import substitution and adopt a system involving greater exposure to international competition was originally part of the economic proposals made a few days after the 1976 coup d'etat. It was only from 1991 onwards, however, that a broad programme was put into effect which enlarged on some trends already identified years before and made substantial changes in the rules regarding trade and financial relations with the rest of the world and the State's role in the economy.

In this context, labour regulations become merely one particular element in the broader question of State intervention. The orthodox view is that these regulations impose high production costs and disincentives for investment which have adversely affected the competitiveness of the production apparatus. The elimination or adaptation of labour market regulations should therefore form part of a more general adaptation of the framework of rules which was essential in order to put Argentina in its proper place in world markets.

In particular, it was stated that non-wage costs were high compared with other countries of the region, with the Southeast Asian nations, and even with some industrialized economies. In a comparative study of the situation of the MERCOSUR countries, it is noted that total labour costs exceed gross wages by $39 \%$ in Argentina, 23\% in Chile and 52\% in Brazil (FIEL, 1992). This greater burden of indirect wages is explained by the high payroll taxes to finance social security and other regulations such as family allowances, unemployment insurance or severance pay.

Negotiated wages and strong trade unions were also blamed for the fact that wages were high and have not responded to the situation of the labour market or levels of productivity. For example, in almost all the activities covered by the FIEL study, gross wages in Argentina were between $10 \%$ and $20 \%$ (or even more in some cases) higher than in Chile and Brazil.

Some regulations, such as those relating to dismissal, not only involve high average costs but also, since they are of a contingent nature, increase uncertainty and investment risks. It is also claimed that regulations on dismissal reduce the flexibility of the labour market. Consequently, it is claimed that these regulations were not only a factor in the high labour 
TABLE 1

Argentina: Wages and productivlty in manufacturing (Indexes)

\begin{tabular}{lcccc}
\hline & Real wage $^{2}$ & Wage cost $^{b}$ & Wage in US\$ & Productivity \\
\hline $1980-1988$ & 137.8 & 90.8 & 76.9 & 86.9 \\
1991 & 100.0 & 100.0 & 100.0 & 100.0 \\
1993 & 105.7 & 137.1 & 135.6 & 135.4 \\
1994 & 109.5 & 144.6 & 146.3 & 144.5 \\
\hline
\end{tabular}

Sounce: Monze (1993) and Sxretter (1995).

-Nominal wage defleted by consumer price index.

bominal wage deflated by nationad nop-agricultural wholesale price index.

costs at the beginning of the period following the adoption of convertibility, but also had a negative effect on the capacity to improve production efficiency. It was claimed that the main way of reducing unit labour costs should be sought with respect to two very closely related aspects: making labour conditions more flexible and increasing the productivity per employee (Bour, 1995, pp. 196-197). The argument would therefore be that greater external flexibility is associated with higher productivity.

Orthodox analysts have therefore repeatedly proposed the reduction of costs and more flexible regulations as means of instantaneously improving competitiveness and allowing productivity to improve on an ongoing basis. They also maintain that this would bring down the relative price of labour and make possible more dynamic growth of employment for a given level of growth of production.

The increase in unemployment $-a$ tendency observed even before the international crisis of late 1994 was identified by some analysts as evidence of the effects of the rigidity and high costs deriving from labour regulations. During the early years of the period following the adoption of convertibility, however, production, productivity and exports all expanded. Even though there was a significant increase in imports, it cannot be argued that the regulations have been a serious obstacle which has prevented firms from adjusting to the new conditions. It has been asserted, however, that the increase in industrial productivity was largely due to a "defensive" strategy on the part of firms (Kosacoff, 1993, pp. 50 -55) and that there was not a significant generalized flow of investments seeking to take advantage of the new rules. It was suggested that this could be explained by the high initial labour costs, which made tradeable goods activities uncompetitive and hence unatractive to investors. It should be borne in mind, however, that the high relative labour costs registered in Argentina in the early years following the adoption of convertibility were largely the consequence of the real exchange rate level. Thus, as may be seen from table 1, which includes data on industry, labour costs in dollars were high, but real wages continued to stand at historically depressed levels (although higher than in the years of hyperinflation). As occurned in other countries of the region (see section IV.2), this tendency became gradually more pronounced during the period 1991-1993, since whereas wages grew in relation to the prices of the consumer shopping basket (although much less than productivity)," industrial prices remained practically unchanged (influenced by the fixed exchange rate), while the prices of services rose, and also, in consequence, nominal wages and the ratios between wages and industrial prices and wages and the exchange rate. This deterioration in the relative prices of tradeable goods greatly slackened as from 1994, so that in that year labour costs increased both in terms of pesos and of dollars (table 1) at a rate closer to that of real wages and also of productivity. ${ }^{12}$ It is even argued that the devalu-

\footnotetext{
11 J. Schvarzer (1994) questions the official figures on the growth of industrial production because be considers that the change in the domestically produced component, which went down in many branches of manufacturing, is not taken into account in the national accounts calculations. When the latter are recalculated in the light of this, the growth rate of the industrial GDP is tos below the official figure for 1994. From this standpoint, the increase in industrial productivity shown in the table would be overestimated.

12 Furthermore, in that year the reductions in the omployer's contributions came into effect. According to Szretter (1995), this led to a reduction in unit wage costs (i.e., the costs which take account of the effect of productivity).
} 
ation of the Argentine peso with respect to the Brazilian Real and the devaluation of the dollar with respect to other strong currencies, together with the improvement in the prices of the products exported by Argentina, were other factors which further increased as from 1994 the beneficial effects on competitiveness exerted by the increase in productivity (Kacef and Machinea, 1995).

At all events, the mere comparison of wages in terms of dollars is not an adequate index of the degree of competitiveness either, since, as shown in

\section{$\mathbf{V}$}

\section{Conclusions}

In the course of this paper it has been argued, first of all, that economic theory is by no means conclusive regarding the impact of labour regulations on competitiveness, since the positions of the different schools of thought are contradictory in many aspects. Empirical studies have shown the very limited relevance of the information put forward regarding these presumed links. This conclusion may be due partly to the intrinsic difficulty of singling out the effects of regulations as compared with other factors.

It may be concluded from the foregoing that, among other things, there are various strategies open to the countries, so that they have more leeway for action that the orthodox positions usually suggest, since many policies aimed at improving equity do not necessarily involve any restrictions on competitiveness. A country can therefore choose its own desired level of social protection. Indeed, labour regulations are by no means identical, even in the closely integrated European countries (De Castro, 1995). The institutional framework of the different countries is the result of a large number of historical and cultural factors, and the range of feasible changes is strongly influenced by such traditions.

Thus, the question of how to improve competítiveness goes beyond merely technical analysis and develops, at least partly, into an examination of income distribution. The orthodox formula, which does not seem to have a sufficient conceptual or empirical basis, holds that there must be a reduction in the quality of life of workers for a sections II and III, it is necessary to take into account the differences in productivity too. In this respect, the FIEL study already referred to shows that in some sectors the differences in wages in terms of dollars between Argentina and other neighbouring countries were more than offset by the big differences in the product/employment ratio.

In short, none of the known country-level studies have contributed substantive empirical proof of the negative repercussions of labour regulations on competitiveness (Feldman, 1995). period whose duration is difficult to predict. While it is true that a country which must increase its trade relations yet has a backward productive base must provide firms with certain initial conditions which will enable them to make up for the diffenences in productivity which may exist, this formula does not seem to be the only one, and it is certainly not the most equitable or necessarily the most effective. In order to generate these conditions it seems perfectly possible to design systems of income redistribution which will make it an attractive proposition to make investments in order to compete internationally without resorting to further reductions in the wages of those who were precisely the persons most heavily affected during the last years of import substitution policies.

The question of the links between labour regulations and competitiveness cannot be seen as a conflict between equity and efficiency. As we have tried to show here, it is realiy a question of differing economic and legal concepts of equity and efficiency. The orthodox approach -at least in its most common form- maintains that there is one and only one way of optimizing efficiency and that it involves temporary sacrifices of equity. The review made here, however, suggests that there is broad leeway for choosing between varions combinations of equity and efficiency, and their selection depends on the power relations of the different social actors and the structure of the State, rather than on infallible, exclusive and indubitable formulas.

(Original: Spanish). 


\section{Bibliography}

Akerlof, G. and J. Yellen (1988): Fairness and unemployment, American Economic Review, vol. 78, No, 2, Nashville, TN, American Economic Association.

Blank, R. and R. Freeman (1994): Evaluating the connection between social protection and economic flexibility, in R. Blank (ed.), Social Protection Versus Economic Reality: Is There a Trade-Off?, Chicago, IL, Chicago University Press.

Bour, J. (1995): Los costos laborales en Argentina, MTSS, Bl libro blanco del empleo en la Argentina, Buenos Aires, Ministerio de Trabajo y Seguridad Social (MTSS).

Boyer, R. (1994): Do labour institutions matter for economic development? A "regulation" approach for the OECD and Latin America, with an extension to Asia, in G. Rodgers (ed.), Workers, Institutions and Economic Growth in Asia, Geneva, International Labour Organisation (ILO), Intemational Institute for Labour Studies (IILS).

Buechtemann, C. (1993): Introduction: Employment security and labor markets, C. Buechtemann (ed.), Employment Security and Labor Market Behavior. Interdisciplinary Approaches and Intemational Evidence, Ithaca, ILR Press.

Caire, G. (1994): Labour standards and international trade, in W. Sengerberger and D. Campbell (eds.), Intemational Labour Standards and Economic Interdependence, Oeneva, ILO.

Caro Figueroa, A. (1992): Las relaciones de trabajo y la competitividad, Derecho del Trabajo, No. LII, A, Buenos Aires, Editorial La Ley.

De Castro, J. A. (1995): Trade and Labour Standards. Using the Wrong Instruments for the Right Cause, Discussion Papers, No. 99, Geneva, United Nations Conference on Trade and Development (UNCTAD)

European Commission (1994a): Crecimiento, competitividad, empleo. Retos y pistas para entrar en el siglo XXI. Libro blanco, Luxembourg.

(1994b): La politica social europea. Un paso adelante para la Unión. Libro blanco, Luxembourg, 27 July.

Feis, H. (1994): International labour legislation in the light of economic theory, in W. Sengerberger and D. Campbell (eds.), International Labour Standards and Economic Interdependence, Geneva, LO.

Feldman, S. (1995): Informe sobre las regulaciones y performance económica en Argentina, paper presented at the Meeting on Labour Market Regulation and Economic Performance: Argentina, Brazil and Chile, Santiago, Chile, ILO.

FIEL (Foundation for Latin American Economic Research) (1992): Costos laborales en el MERCOSUR, Buenos
Aires, Ministry of Foreign and Religious Affairs/ United Nations Development Programme (UNDP).

Freeman, R. (1994): How labor fares in advanced economies, in R. Freeman (ed.), Working Under Different Rules, New York, Russell Sage Foundation.

Gregg, P., S. Machin and A. Manning (1994): High pay, low pay and labour market efficiency, in A. Glyn and D. Miliband (eds.), Paying for Inequality, London, Rivers Oram Press,

Hikino, T. and A. Amsden (1995): La industrialización tardía en perspectiva histórica, Desarrollo económico, vol. 35, No. 137, Buenos Aires, Institute of Economic and Social Development (IDES).

Horton, S., R. Kanbur and D. Mazumdar (1994): Labor markets in an era of adjustment: An overview, in $S$. Horton, R. Kanbur and D. Mazumdar (eds.), Labor Markets in an Era of Adjustment. Case Studies, vol. 2, Washington, D. C., World Bank.

ILO (International Labour Organisation) (1995): World Employment, Geneva.

Jacobi, O. (1994): Competitive advantages of European, American and Japanese industrial relations, Fourth Regional Congress of the International Industrial Relations Association (IIRA), Helsinki.

Kacef, O. and J, Machinea (1995): Cambios recientes en la estructura de precios relativos, Nota, No. 54, Buenos Aires, Instituto de Desarrollo Industrial (IDI).

Kosacoff, B. (1993): La industria argentina: un proceso de reestructuración desarticulada, in B. Kosacoff and others, El desafio de la competitividad. La industria argentina en transformación. Buenos Aires, Economic Commission for Latin America and the Caribbean (ECLAC) Alianza Editorial.

Marshall, A. (1994): Consecuencias económicas de los regímenes de protección de los trabajadores en América Latina, Revissa Intemacional del Trabajo, vol. 113, No. 1, Geneva, ILO, International Labour Office.

Mazumdar, D. (1994): The Republic of Korea, in S. Horton, R. Kanbur and D. Mazumdar (eds.), Labor Markets in an Era of Adjustment. Case Studies, vol. 2, Washington, D. C., World Bank.

Monza, A. (1993): Costo laboral y competitividad, Estudios del trabajo, No. 6. Buenos Aires, ASET, second semester.

OECD (Organization for Economic Cooperation and Development) (1994): Labour standards and economic integration, Employment Outlook, Paris, July. (1996): Les echanges et les normes du travail, Paris, March.

Park, Y. (1994a): Contemporary challenges to labour standards resulting from globalization: The case of 
Korea, in W. Sengerberger and D. Campbell (eds.), Intermational Labour Standards And Economic Interdependence, Geneva, ILO.

(1994b): State regulation, the labour market and economic development: The Republic of Korea, in G. Rodgers (ed.), Workers, Institutions and Economic Growth in Asia, Geneva, ILO, IEL.

Pfaller, A., I. Gough and G. Therborn (eds.) (1993): Competitividad económica y estado de bienestar. Estudio comparativo de cinco pafses avanzados, Madrid, Ministerio de Trabajo y Asumtos Sociales.

Przeworsky, A. (1987): Marxismo y elección racional, Zona, No. 45, Madrid, Editorial Pablo Iglesias.

Schvarzer, J. (1994): La producción argentina en 1994, Buenos Aires, mimeo.

Self, P. (1993): Government by the Market? Boulder, CO, Westview Press.

Sengerberger, W. and D. Campbell (eds.) (1994): International Labour Standards and Economic Interdependence, Geneva, ILO.
Standing, G. (1992): Ajuste estructural y políticas labomales; hacia el ajuste social?, Estudios del trabajo, No. 3, Geneva, ilo.

Stiglitz, J. (1987): The causes and consequences of the dependence of quality gn price, Journal of Economic Literature, vol. XXV, No. 1, Nashville, TN, American Economic Association.

Szretter, H. (1995): Argentina: casto laboral y ventajas competitivas de la industria, Buenos Aires, mimeo.

Tokman, V. and D. Martinez (1995): The impact of labour costs on competitiveness and worker protection in the manufacturing sector of Latin America, paper presented at the Conference on Labour Market Policy in Canada and Latin America Under Economic Integration, Toronto, University of Toronto, December.

Von Potobsky, G. (1995): La regulación laboral a nivel nacional: ¿traba o encuadramiento favorable a un desarrollo sostenido?, Relaciones laborales y seguridad social, Vol. 1, No. 2, Buenos Aires, Ediciones Interoceanicas S. A. 